\title{
Fishmeal Replacement with Hermetia illucens Meal in Aquafeeds: Effects on Zebrafish Growth Performances, Intestinal Morphometry, and Enzymology
}

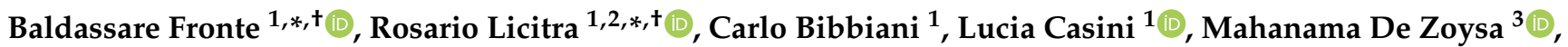 \\ Vincenzo Miragliotta ${ }^{1}$, Simona Sagona ${ }^{1,4}\left(\mathbb{D}\right.$, Francesca Coppola ${ }^{1}\left(\mathbb{D}\right.$, Letizia Brogi ${ }^{1,5}$ and Francesca Abramo ${ }^{1} \mathbb{C}$
}

1 Department of Veterinary Science, University of Pisa, 56126 Pisa, Italy; carlo.bibbiani@unipi.it (C.B.); lucia.casini@unipi.it (L.C.); vincenzo.miragliotta@unipi.it (V.M.); simona.sagona@unipi.it (S.S.); francesca.coppola@vet.unipi.it (F.C.); letizia.brogi@sns.it (L.B.); francesca.abramo@unipi.it (F.A.)

2 Neurobiology and Molecular Medicine, IRCCS Stella Maris, 56128 Pisa, Italy

3 College of Veterinary Medicine and Research Institute of Veterinary Medicine, Chungnam National University, Daejeon 34134, Korea; mahanama@cnu.ac.kr

4 Department of Pharmacy, University of Pisa, 56126 Pisa, Italy

5 BIO@SNS, Scuola Normale Superiore, 56126 Pisa, Italy

* Correspondence: baldassare.fronte@unipi.it (B.F.); rosario.licitra@fsm.unipi.it (R.L.)

+ These authors contributed equally to this work.

check for updates

Citation: Fronte, B.; Licitra, R.; Bibbiani, C.; Casini, L.; De Zoysa, M.; Miragliotta, V.; Sagona, S.; Coppola,

F.; Brogi, L.; Abramo, F. Fishmeal Replacement with Hermetia illucens Meal in Aquafeeds: Effects on Zebrafish Growth Performances, Intestinal Morphometry, and Enzymology. Fishes 2021, 6, 28. https://doi.org/10.3390/fishes 6030028

Received: 12 June 2021

Accepted: 3 August 2021

Published: 5 August 2021

Publisher's Note: MDPI stays neutral with regard to jurisdictional claims in published maps and institutional affiliations.

Copyright: (C) 2021 by the authors Licensee MDPI, Basel, Switzerland. This article is an open access article distributed under the terms and conditions of the Creative Commons Attribution (CC BY) license (https:// creativecommons.org/licenses/by/ $4.0 /)$
Abstract: Fishmeal (FM) is still the most important protein source in aquafeeds. However, due to the reduction of wild fish stocks used for FM production, its manufacturing it is now unsustainable. Insect meal represents a valid alternative to FM, due to the low carbon footprint of its production and its high nutritional value. The aim of this study was to investigate the potentials of replacing FM with black soldier fly (Hermetia illucens) meal (HIM) in aquafeeds, using zebrafish as the animal model. Four diets were formulated with increasing HIM/FM replacement rate (the control diet contained 20\% FM). Mortality rates, growth performances, and feed consumptions were measured, and fish intestine samples were collected for histological and enzymatic analysis. After 49 days, all groups almost tripled their initial body weight (cumulative body weight gain ranged between 143.9 and $155.2 \mathrm{mg}$ ), and no statistically significant differences among treatments were observed in relation to growth performances and histological traits. Contrarily, trypsin, alkaline phosphatases, and alpha amylase-glucoamylase activities were significantly reduced when the FM replacement rate was increased. In conclusion, HIM may represent an alternative to FM, since no adverse effects were observed when it was included up to $20 \%$ in the zebrafish diet, even when replacing $100 \%$ of the FM.

Keywords: black soldier fly; digestive enzymes; fishmeal; growth performance; Hermetia illucens; insect meal; intestinal morphometry; nutrition; protein source; zebrafish

\section{Introduction}

Fishmeal (FM) is still one of the most important protein source in aquafeeds, especially for carnivorous fishes and crustaceans [1]. However, due to the reduction of wild fish stocks used for FM production, its manufacturing it is no longer sustainable [2,3]. So far, FM in aquafeeds has been replaced mainly with vegetable ingredients such as cereals and legumes [1], and several studies have reported that FM can be successfully partially replaced by plant sources [4-6]. Unfortunately, these ingredients are often characterized by unbalanced amino acid profiles, low palatability, presence of anti-nutritional factors, and limited digestibility rates $[7,8]$, with these impairing fish growth and welfare when used to fully replace FM.

In this context, insect meal may represent a valid alternative protein source due to its reduced carbon footprint and its high nutritional value [9]. Its use is also highly suggested in low-carbon rearing systems such as Integrated Multi-Trophic Aquaculture (IMTA) and 
recent IMTA evolution [10]. Insects are characterized by low energy-input requirements and emissions of greenhouse gases and ammonia, and a very favorable feed conversion rate [11]. According to the concept of the circular economy, insects can be raised on a wide array of organic wastes [12]. This aspect makes insect production highly sustainable from both the environmental and the economic points of view [13]. Precise information on insect meal market prices are difficult to find; however, Arru et al. [3] reported that the average market price of fish meal was around $1.48 \mathrm{EUR} / \mathrm{kg}$, and the price of insect-derived proteins could become competitive with that of FM by 2023 [3]. Finally, since July 2017, an EU regulation has allowed the use of insect meal in aquafeeds (Commission Regulation 2017/893).

Insects are already part of the natural diet of many fish species, and several studies have already demonstrated that insect meal provides nutrients that are of high biological value and are characterized by a favorable digestibility rate [14]. Moreover, though the nutrient composition of insects varies according to the species and the stage of biological development, and their composition can be manipulated by using specific culture substrates and technological processes [13]. Hence, it seems that insect meal can be fruitfully used as feed for many fish species [9,14-16], and promising results have been obtained even in relation to the organoleptic quality of fish fillets $[17,18]$.

Recent literature suggests that black soldier fly (Hermetia illucens) (HI) is one of the most promising insect species for producing insect meal, thanks to its excellent nutritional profile and its suitability for intensive production [19]. HI larvae can be fed on animal manure or plant refuse, allowing the conversion of low-value organic waste into proteinrich biomass [20]. In fact, crude protein content of Hermetia illucens meal (HIM) may vary from 30 to $60 \%$ [21,22]. HIM has been tested to replace FM, partially or totally, in the diet of several fish species, and overall, no negative impacts on fish health and performances have been reported [14,17,23].

Although several studies on the effect of FM replacement on gut traits and histological modifications have been performed in several fish species, such as gilthead sea bream (Sparus aurata) [24] and European sea bass (Dicentrarchus labrax) [25], there is still a lack of histological data in relation to the FM replacement with insect meal in the aquaculture research sector. As observed in other animals, fish digestive physiology and nutrient utilization depend on gut morphology and digestive enzymatic activity [26,27]. In fish, trypsin, alkaline phosphatase, and alpha amylase are commonly used in studies evaluating digestive physiology [26,28-32]. In zebrafish, trypsin is the main alkaline proteolytic enzyme during early stages [27]. Alkaline phosphatase is an endogenous protein expressed by the intestinal epithelium that plays a vital role in maintaining gut homeostasis [33]. Alpha amylase is an enzyme that hydrolyses starch and glycogen that can be modulated by diet [34]. Arani et al. [35] assessed the effects of probiotic bacterium Pediococcus acidilactici supplementation on zebrafish amylase, lipase, protease and alkaline phosphatase, and suggested that the enhancement of digestive enzyme activity via improving the potential of digestion exerted a positive effect on the growth indices. Research studies on the effect of insect meal diet inclusion on digestive enzymes activity of fish are still limited. However, the few available studies suggest that enzyme activity is not affected by dietary insect meal inclusions in fish diets [36,37].

The cyprinid zebrafish (Danio rerio) is a widely used animal model in biomedical research [38-40], and several authors have proposed this freshwater fish as a suitable model for aquaculture nutrition research [41-45]. Among others, key factors of the spread of zebrafish as an animal model are its small size, simple management requirements, high fecundity, fast growth, and short life cycle [46]. Moreover, the use of zebrafish as an animal model allows the assessment of numerous dietary parameters in less time and at lower cost than in traditional farmed fish species. Despite the fact that cyprinids do not possess a true stomach, the enzyme characteristic of the vertebrate stomach are still present in the zebrafish digestive tract, irrespective of its anatomy [42]. 
As mentioned above, additional data on the effect of FM replacement with insect meal are still required, notably in relation to histological gut traits and activity of digestive enzymes. Moreover, to the best of our knowledge, the histological and enzymatic effects of total FM replacement with HIM has never been investigated in adult zebrafish. For these reasons, the aim of this study was to evaluate the effects of replacing different levels of FM with HIM, using zebrafish as the animal model. The effects of the tested diets were investigated on mortality rate, growth performances, feed consumption, and feed conversion rate. Intestinal histological traits and enzymatic activities were also evaluated.

\section{Materials and Methods}

\subsection{Rearing System and Experimental Conditions}

To carry out the study, a "stand-alone" for zebrafish husbandry was built according to Paige et al. [47]. The stand-alone consisted of a closed recirculating system, equipped with a thermo-regulation device, biological and UV filters, and 32 tanks (Tecniplast@ S.p.A., Buguggiate, Italy) of $3.5 \mathrm{~L}$ capacity each. Based on the suggestion of Lawrence [48] for zebrafish management, water flow was set at $2 \mathrm{~L} / \mathrm{h}$; the temperature was $28 \pm 0.5^{\circ} \mathrm{C}$; electrical conductivity was maintained between 600 and $800 \mu \mathrm{S} / \mathrm{cm}$; dissolved oxygen was above $7 \mathrm{mg} / \mathrm{L}$; and ammonia, nitrites, and nitrates were kept below 1, 0.25, and $50 \mathrm{mg} / \mathrm{L}$, respectively. The photoperiod was kept at $12 \mathrm{~h}$ of light and $12 \mathrm{~h}$ of dark.

\subsection{Fish Management}

The zebrafish juveniles (wild-type, AB strain) used in the experimental trial were full siblings, produced according to the indications of Westerfield [49]. In the early stages, larvae and juveniles were fed 4 times per day, twice with a commercial feed (Zebrafish Management Ltd., Winchester, UK) and twice with Artemia salina (INVE SEPART Artemia Cysts AF430, INVE Aquaculture $@$, Dendermonde, Belgium); both the commercial feed and Artemia salina were administrated until satiation, as described by Lawrence [48]. At 60 days post-fertilization (dpf), 320 individuals were selected, anesthetized using $0.168 \mathrm{mg} / \mathrm{mL}$ of tricaine solution (MS-222, Sigma $₫$, St. Louis, MO, USA), individually photographed and weighed, and finally randomly allocated into 16 tanks (20 fish per tank; 5.7 fish/L). Fish initial body weight (BWi) was $85.3 \pm 25.58 \mathrm{mg}$ (mean \pm standard deviation).

\subsection{Experimental Design and Diet Formulations}

To carry out the trial, a randomized block experimental design including 4 groups and 4 replicates was used. Thus, 4 diets were formulated according to the HIM/FM replacement as follows: 0\% HIM and 20\% FM (0\% FM replacement), 5\% HIM and 15\% FM (25\% FM replacement), 10\% HIM and 10\% FM (50\% FM replacement), and 20\% HIM and $0 \%$ FM (100\% FM replacement). These diets were then supplied to the groups, which were named HI-0 (control), HI-25, HI-50, and HI-100, respectively, for a total of 49 days. The HIM was derived from black soldier fly larvae (Insect Protein Meal ${ }^{\circledR}$, Protix@, Dongen, Netherlands). The experimental diets were isoenergetic, isoproteic, and formulated to meet the specific nutritional requirements of fishes [50]. Finally, the experimental extruded feeds were produced by Sparos@ (Olhão, Portugal); their compositions and the proximate analysis are given in Tables 1 and 2.

During the experimental period, fish feeding behavior, feed attractiveness, and other technological feed traits such as floating behavior and water imbibition were visually monitored to detect possible macroscopic differences between diets. 
Table 1. Ingredient composition and proximate analysis of experimental diets ( $\%$ on a dry-matter basis).

\begin{tabular}{ccccc}
\hline Diet Ingredients & HI-0 & HI-25 & HI-50 & HI-100 \\
\hline Black soldier fly larvae meal $^{2}$ & - & 5 & 10 & 20 \\
Fishmeal & 20 & 15 & 10 & - \\
Predigested fishmeal & 7.7 & 7.7 & 7.7 & 7.7 \\
Squid meal & 14 & 14.5 & 15 & 15.5 \\
Fish gelatin & 2.5 & 2.5 & 2.5 & 2.5 \\
Soy protein concentrate & 5 & 5 & 5 & 5 \\
Pea protein concentrate & 5 & 4.5 & 4.5 & 5 \\
Wheat gluten & 14 & 14.5 & 15.5 & 16 \\
Wheat meal & 15.5 & 15 & 13.5 & 13 \\
Fish oil & 4.5 & 4.5 & 4.5 & 4 \\
Vitamin and mineral premix & 1 & 1 & 1 & 1 \\
Vitamin E & 0.03 & 0.03 & 0.03 & 0.03 \\
Brewer's yeast & 4 & 4 & 4 & 4 \\
Soy lecithin & 6.5 & 6.5 & 6.5 & 6 \\
Antioxidant powder & 0.2 & 0.2 & 0.2 & 0.2 \\
Sodium propionate & 0.1 & 0.1 & 0.1 & 0.1 \\
Proximate analyses & & & & \\
Crude protein & 60.4 & 60 & 60.2 & 59.8 \\
Crude lipid & 15.2 & 15.5 & 15.9 & 15.5 \\
Fiber & 0.8 & 1.4 & 2 & 3.3 \\
Starch & 12.1 & 11.8 & 10.9 & 10.6 \\
Ash & 5 & 4.7 & 4.4 & 3.8 \\
Gross energy (kJ/g) & 21.9 & 21.9 & 21.8 & 21.6
\end{tabular}

${ }^{1}$ Black soldier fly larvae meal (crude protein: $60 \%$; crude lipid: $14.7 \%$; fiber: $12.6 \%$; ash: $7.4 \%$; gross energy: $19.9 \mathrm{~kJ} / \mathrm{g}$ ). ${ }^{2}$ Fishmeal 70 LT FF Skagen (crude protein: 76.8\%; crude lipid 8.8\%; fiber: $0 \%$; ash: $13.6 \%$; gross energy: $21.9 \mathrm{~kJ} / \mathrm{g})$.

Table 2. Amino acid, mineral, vitamin, and fatty acid composition of experimental diets.

\begin{tabular}{|c|c|c|c|c|}
\hline Diets & HI-0 & HI-25 & HI-50 & HI-100 \\
\hline \multicolumn{5}{|c|}{ Amino Acids (g 100/g of protein) } \\
\hline Arginine & 4.4 & 5.5 & 6.5 & 8.6 \\
\hline Histidine & 1.2 & 2.2 & 3.1 & 5.0 \\
\hline Isoleucine & 2.5 & 3.6 & 4.7 & 7.0 \\
\hline Leucine & 4.4 & 6.2 & 8.0 & 11.6 \\
\hline Lysine & 4.0 & 5.4 & 6.8 & 9.7 \\
\hline Threonine & 2.3 & 3.3 & 4.3 & 6.3 \\
\hline Tryptophan & 0.4 & 0.9 & 1.3 & 2.2 \\
\hline Valine & 2.6 & 4.4 & 6.2 & 9.8 \\
\hline Methionine + Cysteine & 1.9 & 2.5 & 3.1 & 4.2 \\
\hline Phenylalanine + Tyrosine & 4.8 & 5 & 5.3 & 5.8 \\
\hline Taurine & 0.2 & 0.1 & 0.1 & 0.1 \\
\hline \multicolumn{5}{|l|}{ Minerals and Vitamins } \\
\hline Total P (\%) & 0.8 & 0.8 & 0.7 & 0.6 \\
\hline Available P (\%) & 0.6 & 0.6 & 0.5 & 0.4 \\
\hline Phytate P (\%) & 0.2 & 0.1 & 0.1 & 0.1 \\
\hline $\mathrm{Ca}(\%)$ & 1.0 & 0.9 & 0.8 & 0.6 \\
\hline $\mathrm{Ca} / \mathrm{P}$ & 1.2 & 1.2 & 1.1 & 1.0 \\
\hline $\mathrm{Na}(\%)$ & 0.3 & 0.2 & 0.2 & 0.0 \\
\hline $\mathrm{K}(\%)$ & 0.2 & 0.2 & 0.1 & 0.0 \\
\hline $\operatorname{Mn}(\mathrm{mg} / \mathrm{kg})$ & 11.3 & 11 & 10.7 & 10.1 \\
\hline $\mathrm{Zn}(\mathrm{mg} / \mathrm{kg})$ & 23.1 & 19.7 & 16.2 & 9.4 \\
\hline $\mathrm{Fe}(\mathrm{mg} / \mathrm{kg})$ & 26.3 & 21.2 & 16.2 & 6.1 \\
\hline $\mathrm{Cu}(\mathrm{mg} / \mathrm{kg})$ & 10 & 9.8 & 9.6 & 9.2 \\
\hline $\mathrm{Mg}(\mathrm{mg} / \mathrm{kg})$ & 515 & 386.3 & 257.5 & 0.0 \\
\hline Vit C (mg/kg) & 1020.4 & 1020.4 & 1020.4 & 1020.4 \\
\hline Vit E (mg/kg) & 255.1 & 255.1 & 255.1 & 255.1 \\
\hline Vit D (IU/kg) & 2347.3 & 2293.6 & 2240 & 2122.5 \\
\hline
\end{tabular}


Table 2. Cont.

\begin{tabular}{lcccc}
\hline \multicolumn{1}{c}{ Diets } & HI-0 & HI-25 & HI-50 & HI-100 \\
\hline Fatty Acids (\%) & & & & \\
C14 & 0.6 & 0.5 & 0.5 & 0.4 \\
C16 & 1.2 & 1.1 & 1.0 & 0.7 \\
C18:1n9 & 0.9 & 0.9 & 0.8 & 0.6 \\
C18:2n6 (LNA) & 0.2 & 0.2 & 0.2 & 0.2 \\
C18:3n3 (ALA) & 0.1 & 0.1 & 0.1 & 0.1 \\
C20:4n6 (ARA) & 0.02 & 0.02 & 0.01 & 0.01 \\
C20:5n3 (EPA) & 0.7 & 0.6 & 0.6 & 0.5 \\
C22:6n3 (DHA) & 0.7 & 0.7 & 0.6 & 0.5 \\
DHA/EPA & 1.1 & 1.1 & 1.0 & 1.0 \\
SFA & 2.2 & 2.0 & 1.8 & 1.3 \\
MUFA & 3.1 & 2.9 & 2.8 & 2.3 \\
PUFA & 2.0 & 1.9 & 1.7 & 1.3 \\
\hline Abrifis
\end{tabular}

Abbreviations: SFA, saturated fatty acids; MUFA, monounsaturated fatty acids; PUFA: polyunsaturated fatty acids.

\subsection{Experimental Procedures and Measurements}

On days $0,7,14,21,35$, and 49, all fishes were anesthetized (MS-222-Sigma@, St. Louis, MO, USA), photographed with a digital camera, and individually weighed. Afterwards, by comparing the photos taken at different time points (e.g., day 7 and day 0 ), the fishes of each tank were individually identified. Fish identification was based on the observation of the fish sex, individual body shape, and phenotypic peculiar details such as pigmentation pattern (livery details), tail, jaw, head, and the shape of other body parts, according to Fronte et al. [51]. An example of the identification procedure is described in Figure 1.
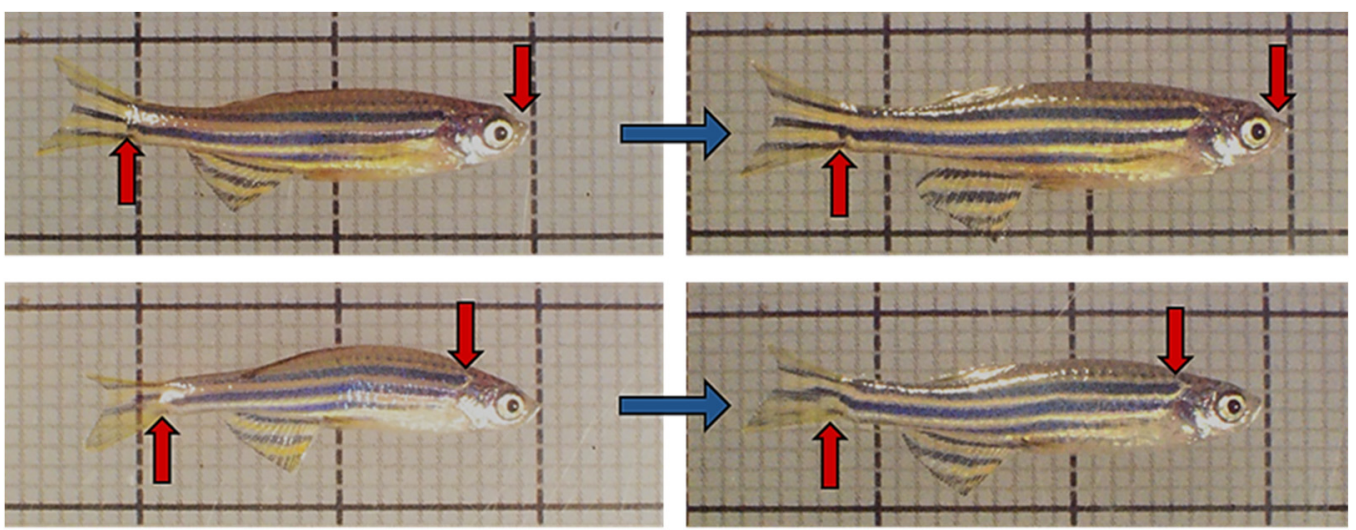

Figure 1. Example of the identification of two fishes through the observation of individual body and livery phenotypic traits (red arrows); photos on the same line (blue arrows) refer to the same fish photographed at an earlier and later time point (the pictures show 2 weeks of difference).

For each subject, the following data were also recorded: initial body weight (BWi), final body weight (BWf), body weight gain (BWg) as a difference between $\mathrm{BWf}$ and $\mathrm{BWi}$, and feed conversion rate (FCR) as feed intake/BWg. Furthermore, fish survival was recorded on a daily basis. Visual evaluations of feed palatability, standard behavior, and overall welfare of the reared animals also was carried out daily to detect possible signs of pathology or distress.

\subsection{Intestine Sampling}

At the end of the experimental period and after $24 \mathrm{~h}$ of fasting, 20 fish from each group were sacrificed by overdose of anesthesia $(0.25 \mathrm{mg} / \mathrm{mL}$, MS-222, Sigma $\odot$, St. Louis, MO, USA), and the entire digestive tract was removed and washed with saline solution. For enzymatic analyses, portions of the midgut were dissected from 20 fish of each group and stored at $-20{ }^{\circ} \mathrm{C}$ until use. To perform histological examination, portions of the midgut 
were obtained from 20 fish of the HI- 0 group and 20 fish of the HI-100 group using a stereomicroscope, then these were fixed in a $10 \%$ buffered formalin solution $(\mathrm{pH} 7.4)$ and routinely processed. Paraffin embedding was accomplished to obtain longitudinal sections of the intestine.

\subsection{Digestive Enzyme Activities}

All chemicals were purchased from Sigma $\odot$ (St. Louis, MO, USA).

\subsubsection{Protein Extraction}

Protein extraction was performed according to the method described by Silva et al. [52] with some modifications. Briefly, frozen gut portions of each sample were mixed with $200 \mu \mathrm{L}$ of $0.1 \mathrm{M} \mathrm{CaCl}^{2}$, homogenized with a pestle of Teflon, and centrifuged at $9000 \mathrm{rpm}$ for $10 \mathrm{~min}$. The supernatant was collected and centrifuged again at $3400 \mathrm{rpm}$ for $20 \mathrm{~min}$. The pellet was collected, suspended in $0.1 \mathrm{M} \mathrm{pH}$ 7.4 Tris-Hepes buffer, and stored at $-20^{\circ} \mathrm{C}$ until enzyme assays. Total soluble proteins were measured with a Qubit fluorimeter (Invitrogen $\odot$, Carlsbad, CA, USA) according to Mazzei et al. [53].

\subsubsection{Enzyme Assays}

1. Trypsin activity was determined according to Hassanabatar et al. [54] using $0.1 \mathrm{mM}$ $\mathrm{N}-\alpha$-benzoyl-DL-arginine-p-nitroanilide hydrochloride (BAPNA) as the substrate in $50 \mathrm{mM}$ tris- $\mathrm{HCl} \mathrm{pH} 7.5$ and $20 \mathrm{mM} \mathrm{CaCl}$. Samples were added to the substrate and incubated at $37^{\circ} \mathrm{C}$. The absorbance was recorded at $410 \mathrm{~nm}$ for 3 min with an Ultrospec 2100 UV pro spectrophotometer (Amersham Biosciences $\odot$, Little Chalfont, UK). The results of the trypsin assay were expressed as unit/mg protein;

2. Alkaline phosphatase activity was determined according to Hassanabatar et al. [54,55] using $2 \mathrm{mM}$ 4-nitrophenyl phosphate (4 pNPP) as the substrate in $30 \mathrm{mM} \mathrm{Na}_{2} \mathrm{CO}_{3}$ buffer ( $\mathrm{pH}$ 9.8). Samples were added to the substrate and incubated at $37^{\circ} \mathrm{C}$. The reaction was stopped by the addition of $0.1 \mathrm{~N} \mathrm{NaOH}$. Absorbance was recorded at $407 \mathrm{~nm}$ for $20 \mathrm{~min}$ with an Ultrospec $2100 \mathrm{UV}$ pro spectrophotometer (Amersham Biosciences $\odot$, Little Chalfont, UK). Results of the alkaline phosphatase assay were expressed as $\mu \mathrm{g}$ BTEE (N-Benzoyl-L-tyrosine ethyl ester)/min $\mathrm{mL} \mu \mathrm{g}$ protein;

3. Alpha-amylase and glucoamylase activities were measured according to Xiao et al. [56] using soluble starch $(2 \mathrm{~g} / \mathrm{L})$ as the substrate. Samples were added to the substrate and incubated at $50{ }^{\circ} \mathrm{C}$. The reaction was stopped by the addition of $1 \mathrm{M} \mathrm{HCl}$. After the addition of iodine reagent ( $5 \mathrm{mM} \mathrm{I} 2$ and $5 \mathrm{mM} \mathrm{KI}$ ), absorbance of samples was recorded at $580 \mathrm{~nm}$ with an Ultrospec $2100 \mathrm{UV}$ pro spectrophotometer (Amersham Biosciences $\odot$, Little Chalfont, UK). Results of the alpha-amylase and glucoamylase assay were expressed as unit/mL mg protein.

\subsection{Histological Examination and Morphometry}

For morphological measurement, the longitudinal-oriented intestine samples were sliced into $5 \mu \mathrm{m}$ sections and stained with hematoxylin and eosin (H\&E) and Alcian blue ( $\mathrm{pH}$ 2.5). Sections were then examined using a light microscope (Nikon, Eclipse 80i, Calenzano, Florence, Italy) connected to a PC via a Nikon digital system (Digital Sight DSU1). Representative images were acquired using NIS-Elements to perform morphometrical analysis on the following parameters: intestinal villi and wall height, villi width, and goblet cell number. The height of each villus was manually outlined from its apex to the tunica muscularis and to the serosa; wall thickness was measured by manually tracing perpendicular segments (at regular intervals) to an imaginary line connecting the surface of adjacent villi to the tunica muscularis and to the serosa; villi width was obtained by manually tracing perpendicular segments to the midportion of each villus. Since evident differences in the wall thickness were observed between the two sides of the intestine, two independent measures were collected from the two anatomical regions, arbitrarily named dorsal and ventral, with the dorsal being thicker. The number of Alcian blue goblets were 
counted per field at $40 \times$, and their total number $/ \mathrm{mm}^{2}$ of mucosal surface was recorded (see Figure 2).

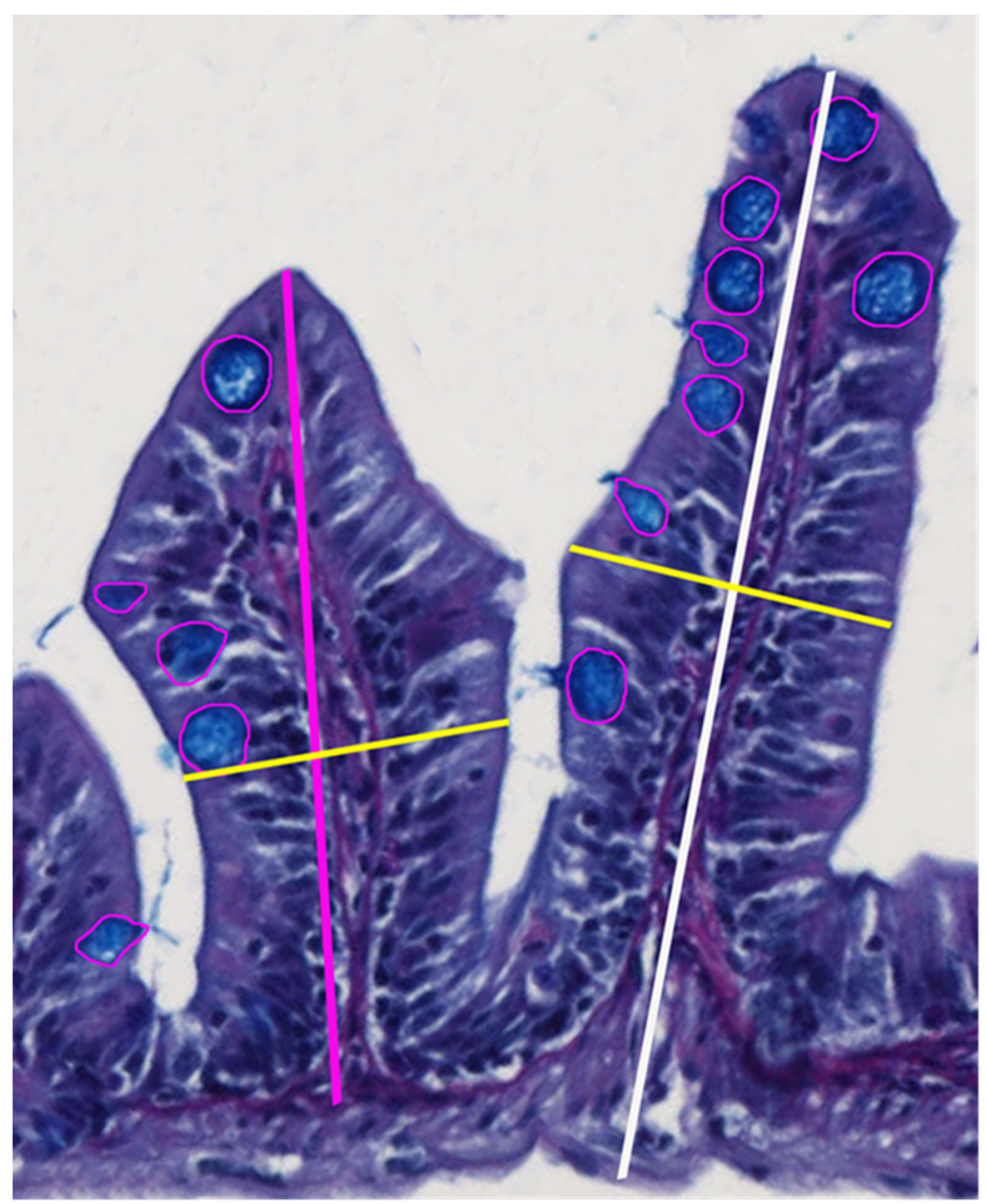

Figure 2. Photomicrograph of Alcian blue stained intestinal wall $(40 \times)$. The purple and white lines indicate the height of a villus from its apex to the tunica muscularis and to the serosa, respectively. The yellow lines indicate two measurements of the intestinal villi width; goblet cells present in this frame are outlined in purple.

\subsection{Statistical Analysis}

Survival-rate data were analyzed using the Kaplan-Meier method followed by a log-rank test to detect possible differences between groups. The data related to live weight, body weight gain, and feed intake at different time points were analyzed using analysis of variance (ANOVA), and differences among groups were determined with Tukey's HSD test. Finally, FCR data were analyzed by ANOVA, covariating the feed intake of each group for the respective body weight gain, and again, differences among groups were tested with Tukey's HSD test. Mean values related to intestinal morphometry of groups HI-0 and HI-100 were tested using a Student's $t$-test.

Data related to enzymatic activity were analyzed using the following criteria: data residues, obtained with a preliminary nonparametric Kruskal-Wallis test, were tested for normal distribution. Since trypsin and alkaline phosphatase activities were normally distributed, data were analyzed by ANOVA test followed by Tukey's HSD test. Alpha amylase-glucoamylase activities were not normally distributed, and data were analyzed using a nonparametric Kruskal-Wallis test. Since significant differences were found among groups, means were ordered and followed by a pairwise comparison with a Wilcoxon test. Differences among groups were considered statistically significant for $p<0.05\left(\mathrm{JMP}^{\circledR} 8\right.$, SAS Institute Inc.@, Cary, NC, USA, 2008). 


\section{Results}

No alterations of fish feeding behavior were observed during the experimental period, and the diets containing HIM were macroscopically similar to that containing FM and not HIM.

\subsection{Survival Rate and Growth Performances}

Fish survival rate was similar for all the groups, and no statistically significant differences were observed (Figure S1). Survival rates were equal to $88.75 \%$ in the HI- 0 control group and HI-50 group, $92.5 \%$ in the HI-25 group, and $93.75 \%$ in the HI-100 group.

At the end of the trial, all groups had almost tripled their initial body weight (Table 3). Growth performances such as body weight and body weight gain were similar throughout the considered groups, notably when cumulative parameters were considered. Similarly, feed intake and feed conversion rate did not show differences among treatments, and the observed values varied just slightly among groups (11.6 $\mathrm{mg}$ for feed intake and 0.17 only for FCR).

Table 3. Growth performance parameters in relation to FM replacement rate with HIM.

\begin{tabular}{|c|c|c|c|c|c|c|}
\hline & HI-0 & HI-25 & HI-50 & HI-100 & SEM $^{1}$ & $p$-Value \\
\hline \multicolumn{7}{|l|}{ Body weight (mg) } \\
\hline Day 1 & 84.9 & 85.0 & 85.4 & 86.0 & 1.44 & 0.9932 \\
\hline Day 7 & 109.4 & 114.3 & 114.2 & 113.8 & 2.04 & 0.8008 \\
\hline Day 14 & 136.6 & 143.5 & 142.8 & 139.2 & 2.76 & 0.7903 \\
\hline Day 21 & 152.2 & 164.3 & 163.5 & 158.0 & 3.33 & 0.5459 \\
\hline Day 35 & 178.8 & 191.0 & 189.4 & 182.1 & 3.94 & 0.6512 \\
\hline Day 49 & 228.8 & 236.8 & 240.6 & 229.3 & 4.68 & 0.7687 \\
\hline \multicolumn{7}{|c|}{ Body weight gain (mg) } \\
\hline Day 1-day 7 & 24.5 & 29.3 & 28.8 & 27.8 & 1.25 & 0.5335 \\
\hline Day 8-day 14 & 27.2 & 29.2 & 28.6 & 25.4 & 1.55 & 0.7617 \\
\hline Day 15-day 21 & 15.6 & 20.8 & 20.7 & 18.8 & 1.23 & 0.3767 \\
\hline Day 22-day 35 & 26.6 & 26.7 & 25.9 & 24.1 & 1.63 & 0.7798 \\
\hline Day 36-day 49 & 50.0 & 45.8 & 51.2 & 47.2 & 1.54 & 0.1956 \\
\hline Cumulative BWg & 143.9 & 151.8 & 155.2 & 143.3 & 4.38 & 0.6921 \\
\hline \multicolumn{7}{|l|}{ Feed intake (mg) } \\
\hline Day $1-$ day 7 & 35.3 & 38.7 & 36.6 & 34.7 & 1.02 & 0.8650 \\
\hline Day 8-day 14 & 50.0 & 55.8 & 53.5 & 50.5 & 1.22 & 0.3273 \\
\hline Day 15-day 21 & 49.0 & 48.7 & 45.5 & 46.6 & 0.55 & 0.1112 \\
\hline Day 22-day 35 & 88.3 & 86.5 & 95.3 & 89.9 & 1.31 & 0.7563 \\
\hline Day 36-day 49 & 90.5 & 85.6 & 80.4 & 79.8 & 1.13 & 0.8747 \\
\hline Cumulative FI & 313.1 & 315.3 & 311.3 & 301.5 & 2.94 & 0.5016 \\
\hline \multicolumn{7}{|l|}{ Feed Conversion Rate } \\
\hline Day 1-day 7 & 1.44 & 1.32 & 1.27 & 1.25 & 0.0287 & 0.1468 \\
\hline Day 8-day 14 & 1.84 & 1.91 & 1.87 & 1.99 & 0.0385 & 0.5403 \\
\hline Day 15-day 21 & 3.14 & 2.34 & 2.20 & 2.48 & 0.1124 & 0.0526 \\
\hline Day 22-day 35 & 3.32 & 3.24 & 3.68 & 3.73 & 0.1975 & 0.7594 \\
\hline Day 36-day 49 & 1.81 & 1.87 & 1.57 & 1.69 & 0.0502 & 0.2168 \\
\hline Cumulative FCR & 2.18 & 2.08 & 2.01 & 2.10 & 0.0317 & 0.1791 \\
\hline
\end{tabular}

${ }^{1}$ SEM, standard error of the mean. Abbreviations: BWg, body weight gain; FI, feed intake; FCR, feed conversion rate.

\subsection{Intestinal Morphometry}

The height and width of intestinal villi were not significantly affected by the considered treatments (HI-0 and HI-100). Differences were observed for wall height to the tunica serosa and wall height to the tunica muscularis, in both cases in relation to the ventral side (Table 4). The number of Alcian blue stained goblet cells in the convolute part of the intestine were 95 and $102 / \mathrm{mm}^{2}$ for the control and HI-100 groups, respectively, and no statistically significant differences were observed. 
Table 4. Intestinal morphometry of the HI-0 and HI-100 groups.

\begin{tabular}{ccccc}
\hline & HI-0 & HI-100 & SEM $^{\mathbf{1}}$ & $p$-Value \\
\hline Wall height to tunica serosa, dorsal side & 402 & 393 & 28.0 & 0.0798 \\
Wall height to tunica muscularis, dorsal side & 358 & 353 & 26.0 & 0.0863 \\
Wall height to tunica serosa, ventral side & 301 & 338 & 19.6 & $0.0494^{*}$ \\
Wall height to tunica muscularis, ventral side & 270 & 287 & 18.1 & $0.0271^{*}$ \\
Villi width, dorsal side & 140 & 132 & 8.2 & 0.3248 \\
Villi width, ventral side & 142 & 138 & 7.3 & 0.1221 \\
Villi height to tunica serosa, dorsal side & 355 & 366 & 24.4 & 0.1188 \\
Villi height to tunica muscularis, dorsal side & 317 & 321 & 23.9 & 0.2991 \\
Villi height to tunica serosa, ventral side & 275 & 307 & 18.4 & 0.1155 \\
Villi height to tunica muscularis, ventral side & 248 & 268 & 17.8 & 0.2457 \\
\hline
\end{tabular}

${ }^{1}$ SEM, standard error of the mean. ${ }^{*}$ Significantly different for $p<0.05$.

\subsection{Digestive Enzyme Activities}

On the contrary, the dietary treatments affected the activity of trypsin, alkaline phosphatases, and alpha amylase-glucoamylase at the midgut level. In fact, for all the considered enzymes, a parallel reduction of enzymatic activity was observed with an increasing FM replacement rate, and therefore higher levels of HIM inclusion (Figure 3).

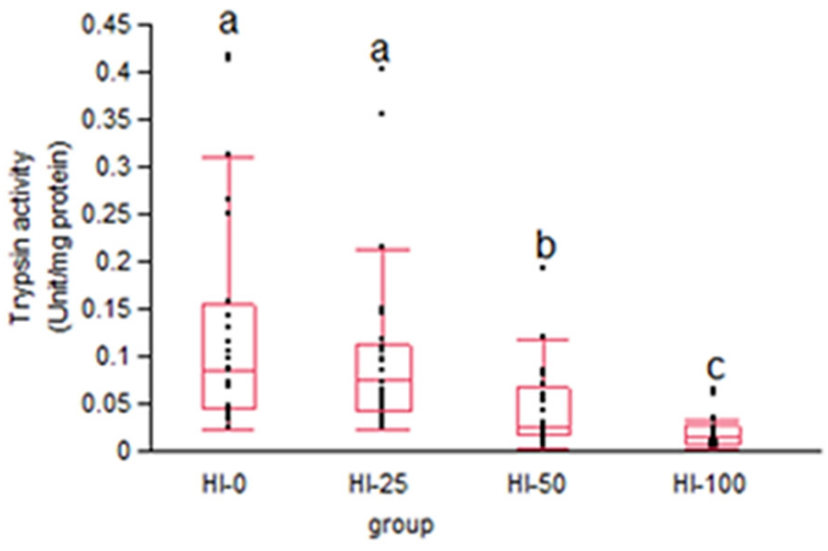

(a)

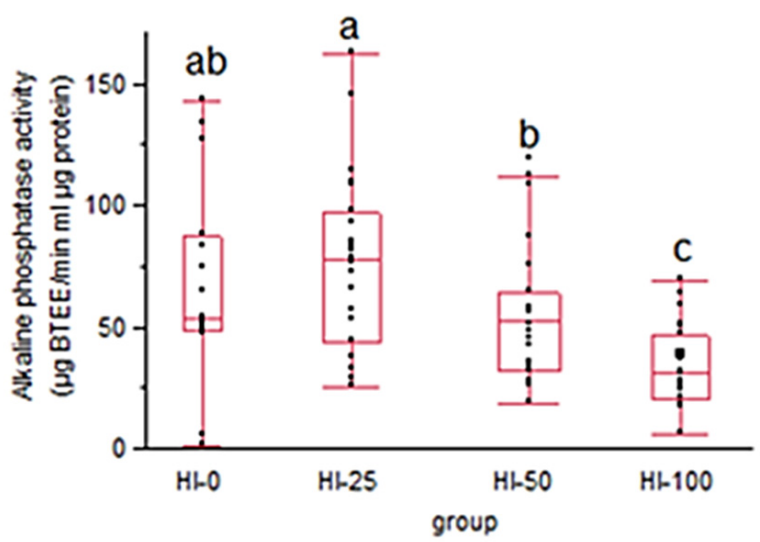

(b)

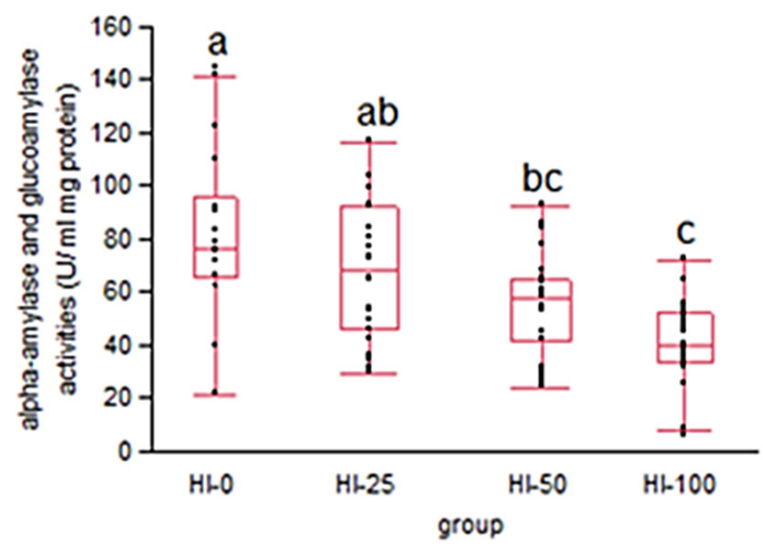

(c)

Figure 3. Enzymatic activities of the midgut among the experimental groups. (a) Trypsin activity; (b) alkaline phosphatase activity; (c) $\alpha$-amylase-glucoamylase activity. Values with different lowercase letters are significantly different $(p<0.0001)$. 
In particular, trypsin activity was significantly reduced when the FM replacement rate was increased from 25 (HI-25) to $50 \%$ (HI-50) $(p=0.001)$, and again from 50 to $100 \%$ (HI-100) $(p=0.02)$. A similar trend also was observed for alkaline phosphatase. In particular, the HI-25 group was statistically different from the HI-50 and HI-100 ( $p=0.035)$ groups, while the control group differed only from the HI-100 group $(p=0.003)$. For alpha amylase-glucoamylase enzymes, the activity showed a significant reduction only when HIM replaced at least $50 \%$ of the FM (HI-50), and a further significant reduction was observed in the HI-100 group, confirming what had already been observed for the other enzymes. Overall, a progressive reduction of enzymatic activity as a consequence of the FM replacement with HIM $(p<0.0001)$ was observed.

\section{Discussion}

\subsection{Growth Parameters}

Previous studies on the partial or total replacement of FM with HIM (with a control diet containing 20\% FM) in the diet of Atlantic salmon (Salmo salar) showed no negative effects on growth performance and feed utilization [17,37]. In addition, Belghit et al. [37] reported that even whole-body composition, nutrient digestibility, and sensory quality of the salmon fillets were not affected by the dietary inclusion of HIM when replacing FM (with a control diet containing 10\% FM). Similarly, the growth performance and feed conversion rate of fish were not affected in both Jian carp (Cyprinus carpio var. Jian) and Nile tilapia (Oreochromis niloticus) when FM was partially or totally replaced with HIM [36,57]. In these cases, HIM was included in the diet up to $10.6 \%$ and $30 \%$, respectively. No differences in growth performance, feed intake, or feed conversion rate were reported in gilthead sea bream, European sea bass, and Japanese sea bass (Lateolabrax japonicus) after partial replacement of FM (30, 45, and 65\%, respectively) with HIM (with control diets containing 100, 32, and 25\% FM, respectively). In these cases, the HIM inclusion rate ranged between 20 and 30\% [58-60]. Furthermore, several studies have suggested that FM replacement rates ranging from 25 to $50 \%$ of HIM (about 10-40\% diet inclusion) in the diet of rainbow trout (Oncorhynchus mykiss) resulted in similar growth and feed conversion rates, as well as comparable slaughtering performances [18,23,61-63]. All the results of the above-mentioned studies are in line with those observed in the present study carried out on zebrafish, in which the replacement of FM with HIM showed no adverse effects on fish growth, feed consumption, and conversion rate. However, Xiao et al. [22] reported that HIM diet inclusion may reduce or improve the fish growth parameters and feed utilization. Partial FM replacements with HIM at rates equal to $13,25,37$, and $48 \%$, corresponding to $5.50,10.8,16.5$, and $22.3 \%$ of HIM diet inclusion, led to the increased growth of yellow catfish (Pelteobagrus fulvidraco). On the contrary, when FM replacement rates were higher than $65 \%$, a reduction in the growth was observed. In the study of Xiao et al. [22] the HIM inclusion levels that worsened the fish growth rates (equal to $34.3,46.2$, and $58.5 \%$ for 65 , 85 , and $100 \%$ FM replacement, respectively), were rather high compared to those used in our research or discussed above.

Reduced feed conversion rates and growth efficiencies of fish fed with diets containing elevated inclusion rates of HIM also have been reported in other species, such as channel catfish (Ictalurus punctatus), blue tilapia (Oreochromis aureus), and turbot (Psetta maxima) $[64,65]$. The reduction in growth performance observed in some species, as suggested by Kroeckel et al. [65], was probably related to the presence of chitin, indigestible by several fish species [66]. Overall, differences observed in fish growth using insect meal as a diet ingredient may be explained by the digestive chitinolytic activity of the single fish species [67]. Nevertheless, due to the differences in insect rearing substrate or processing technologies, as well as fish species and stage, the results among studies are sometimes conflicting or not comparable [62]. In the current study, feed conversion rates were comparable to the data reported for the same species by Yossa et al. [45], and were similar to the values described for numerous aquaculture species, ranging from 1 to 3 [68]. 
Recently, few studies have been carried out on the effects of HIM inclusion in zebrafish diet, both in larvae and adult fish. Partial FM replacement with HIM (25 and 50\% FM replacement and 10.5 and 21\% HIM diet inclusion, respectively), or even the use of a $100 \%$ HIM diet during the first three weeks of life, did not show negative effects on the growth parameters of zebrafish larvae $[67,69]$. On the contrary, when the same dietary treatment described above was supplied for 6 months (from larval to adult stage), Zarantoniello et al. [70] observed reduced growth performances in fish fed the diet with the highest HIM inclusion. A possible explanation of this result could be an unbalanced fatty acid composition of the insect-based diets, characterized by a lower content of highly unsaturated fatty acids and a higher content of saturated fatty acids in comparison to the control diet [70].

Finally, it is worthy to highlight that the protein content of zebrafish diets still varies widely among studies and commercial feeds. For instance, Zarantoniello et al. [70] used a diet protein content of approximately $40 \%$, while $63 \%$ was used in the present study. These differences may sometimes lead to the observation of different results. Unfortunately, zebrafish nutritional requirements are not yet fully determined, and no precise scientific suggestions are still available. Nevertheless, fish mainly rely on protein intake to cover both protein (notably amino acids) and energy requirements [50], and negative effects related to dietary protein excess are mainly reported in relation to nitrogen excretion and water-quality degradation.

\subsection{Intestinal Morphometry}

Regarding gut histology, the results for zebrafish were in line with what has already been reported for Atlantic salmon, where FM replacement with HIM did not show any significant differences between groups for liver and intestine histology [17]; and for rainbow trout and Japanese seabass, where dietary inclusion of HIM did not alter the intestine villus height of fishes [60,61]. Our results also were in accordance with those of Zarantoniello et al. $[69,70]$ and Vargas et al. [67], who reported that zebrafish larvae and adults fed with a diet partially or fully composed in HIM showed no appreciable histological alterations or inflammation processes in the intestinal tract, and only an increase in the goblet cell number as a trend was noted when using HIM as the only feed. However, in Jian carp (Cyprinus carpio var. Jian), while FM replacement with HIM lower than $50 \%$ had no effect on gut morphology, when 75\% of FM was replaced by HIM, apparent pathological changes were observed in the intestine, such as tissue disruption [36].

Different parameters have been used to evaluate morphological differences in different parts of the intestine; one of these was used to demonstrate that both mucosa and muscle layers can separately contribute to the entire thickness, as previously demonstrated during a fiber-rich diet administration in mammals [71]. Mucosa thickness was evaluated either by single-villi height assessment and an overall assessment of the height of the entire mucosa to overcome the low number of villi in a single captured field; moreover, two different measurements were undertaken to assess these parameters in the dorsal and ventral longitudinal sections, respectively; this approach was chosen because evident differences were observed in the wall thickness of the two sides of the intestine (dorsal and ventral). In this regard, it is worthy to highlight that a significant increase of the wall height to the tunica sierosa and the wall height to the tunica muscolaris were observed in fish fed HI-100; in both cases, the increments were observed on the ventral side of the intestine wall. However, it seems possible to hypothesize that the described histological modifications did not negatively affect fish growth. The biological meaning of these observations is still unclear, but our study contributed to establishing baseline values that might help to undertake further studies on biological responses of the digestive tract in zebrafish.

\subsection{Digestive Enzyme Activities}

With regard to the activities of digestive enzymes according to our results, other authors reported that the activity of many intestinal enzymes may be affected by diet composition [72,73]. Literature on the effects of HIM inclusion in aquafeeds on enzyme 
activity of the fish gut is still limited to few species, but overall, it seems that insect-meal inclusion has a mild effect on fish digestive enzymes. In fact, no significant differences were observed as a result of HIM diet inclusion in the activity of intestinal alpha-amylases, trypsin, or lipases of Jian carp [36]; intestinal trypsin and amylase of Japanese seabass [60]; intestinal proteases and amylase of European seabass [60]; and intestinal trypsin of Atlantic salmon [37] using HIM inclusion up to 10-20\%. However, intestinal lipase activity increased with the highest HIM inclusion in the diet of Japanese seabass [60] and, on the contrary, decreased when European seabass were fed using 6.5\% of HIM in diets versus the control and 19.5\% HIM-inclusion diets [59].

In light of this, it seems that the reduced enzyme activities observed in the current study are controversial compared to what has been observed in other fish species, but they were not correlated to an impairment of growth, feed utilization, and heath parameters of fish. Variations in trypsin activity probably occurred because different types of dietary protein require different types of enzymes for its digestion, as suggested by García-Gasca et al. [74]. Reduction of activity of alkaline phosphatase is associated with increased intestinal inflammation, dysbiosis, bacterial translocation, and subsequently systemic inflammation [33]. Alkaline phosphatase in zebrafish is induced during establishment of the microbiota, and plays a crucial role in promoting mucosal tolerance to gut bacteria in zebrafish. In addition, it dephosphorylates microbiota-associated lipopolysaccharide, thereby establishing a homeostatic negative feedback loop that reduces signaling through Toll-like receptors and the tumor necrosis factor receptor, thus preventing excessive intestinal inflammation [75]. It has been suggested that an increase of alkaline phosphatase activity can be considered as an improvement of immune status, so the decrease could be considered a negative diet effect [76]. Recently, Carneiro et al. [77] replaced fish meal with Chlorella sp. meal in a zebrafish diet, and observed that the increase in alkaline phosphatase activity contributed to improving the overall efficiency of zebrafish juvenile digestive and absorptive processes. The resulting decrease in alpha amylase-glucoamylase activities in zebrafish that were fed diets in which HIM replaced at least 50\% of the FM disagreed with Fang and colleagues [78], whose experimental diet administration of carbohydrates to zebrafish suggested $\alpha$-amylase activity could reflect different nutrient requirements at different stages of life. The administration of adult black soldier fly to zebrafish (up to $20 \%$ of diet inclusion) in order to obtain an increase of alpha amylase activity could be interesting, because the adult insect contains a large quantity of chitin, which is a carbohydrate, while the larva is rich in fat. Results showed that the only experimental diet that did not result in significant decreases in all three investigated enzyme activities (trypsin, alkaline phosphatase, and alpha-amylase-glucoamylase activities) compared to the control diet (only FM) was HI-25. Since the enhancement of digestive enzyme activity exerted a positive effect on the growth indices of zebrafish [35], the results suggested that the HI-25 diet may be the only one that could replace the FM diet.

\section{Conclusions}

HIM can be a promising alternative to FM in zebrafish nutrition. In fact, HIM inclusion rates equal to 5,10 , and $20 \%$ of the diet, replacing 25,50 , or $100 \%$ of FM, respectively, did not negatively affect the intestine histology or the main productive performances of zebrafish, such as mortality, feed intake, body weight gain, and feed conversion rate. Instead, some enzyme activities were reduced when the FM replacement rate was increased. In conclusion, the results of the current study suggest that it is possible to replace FM with HIM in zebrafish feeding, and in a broader context, in aquaculture nutrition, since knowledge obtained using zebrafish as experimental models are becoming of primary importance for the aquaculture sector. The performances observed in this research on zebrafish were comparable to those reported in many other fish species, both freshwater and marine, highlighting a strong closeness in terms of utilization of insect-based nutrients between fish species. Further studies designed to test higher HIM inclusion levels in the 
zebrafish diet are needed in order to understand the upper limit of inclusion and expand the knowledge on the use of this promising insect meal in aquafeeds.

Supplementary Materials: The following are available online at https:/ / www.mdpi.com/article/10 .3390 / fishes6030028/s1, Figure S1: Fish survival rate.

Author Contributions: Conceptualization, B.F., R.L., and M.D.Z.; methodology, B.F., R.L., and L.C.; software, B.F. and C.B.; validation, B.F., R.L., and C.B.; formal analysis, L.B., R.L., S.S., F.C., and F.A.; investigation, B.F., R.L., S.S., V.M., and F.A.; resources, B.F., C.B., and F.A.; data curation, B.F., R.L., S.S., V.M., and F.A.; writing-original draft preparation, B.F. and R.L.; writing-review and editing, B.F., R.L., S.S., M.D.Z., L.C., V.M., and F.A.; visualization, C.B. and F.C.; supervision, B.F. and F.A.; project administration, B.F.; funding acquisition, B.F. and C.B. All authors have read and agreed to the published version of the manuscript.

Funding: This research received no external funding.

Institutional Review Board Statement: The study was carried out at the AquaLab and Zebrafish Facility of the Department of Veterinary Science at the University of Pisa (Italy). The research project was authorized by the Committee for Animal Care of the University of Pisa (Prot. No. 21862/2016 of 19/04/2016), in accordance with European Directive No. 63 of 22/09/2010 on the protection of animals used for scientific purposes.

Acknowledgments: We would like to thank Protix@ (Dongen, the Netherlands) for kindly providing the black soldier fly larvae meal used in the trial.

Conflicts of Interest: The authors declare no conflict of interest.

\section{References}

1. Hua, K.; Cobcroft, J.M.; Cole, A.; Condon, K.; Jerry, D.R.; Mangott, A.; Praeger, C.; Vucko, M.J.; Zeng, C.; Zenger, K.R.; et al. The Future of Aquatic Protein: Implications for Protein Sources in Aquaculture Diets. One Earth 2019, 1, 316-329. [CrossRef]

2. FAO. The State of World Fisheries and Aquaculture: Meeting the Sustainable Development Goals; FAO: Rome, Italy, 2018 ; pp. 1-210.

3. Arru, B.; Furesi, R.; Gasco, L.; Madau, F.A.; Pulina, P. The Introduction of Insect Meal into Fish Diet: The First Economic Analysis on European Sea Bass Farming. Sustainability 2019, 11, 1697. [CrossRef]

4. Moniruzzaman, M.; Damusaru, J.H.; Won, S.; Cho, S.J.; Chang, K.H.; Bai, S.C. Effects of partial replacement of dietary fish meal by bioprocessed plant protein concentrates on growth performance, hematology, nutrient digestibility and digestive enzyme activities in juvenile Pacific white shrimp, Litopenaeus, Vannamei. J. Sci. Food Agric. 2020, 100, 1285-1293. [CrossRef] [PubMed]

5. Zhou, F.; Song, W.; Shao, Q.; Peng, X.; Xiao, J.; Hua, Y.; Owari, B.N.; Zhang, T.; Ng, W.K. Partial Replacement of Fish Meal by Fermented Soybean Meal in Diets for Black Sea Bream, Acanthopagrus Schlegelii Juveniles. J. World Aquac. Soc. 2011, 42, 184-197. [CrossRef]

6. Nishshanka, K.M.; Radampola, K.; Bulugahapitiya, V. Effects of partial replacement of dietary fishmeal using plant-protein sources on the growth performance, coloration and liver histology of guppy fry (Poecilia reticulata) in outdoor farming conditions. J. Appl. Aquac. 2021, 2021, 1-19. [CrossRef]

7. Francis, G.; Makkar, H.P.S.; Becker, K. Antinutritional factors present in plant-derived alternate fish feed ingredients and their effects in fish. Aquaculture 2001, 199, 197-227. [CrossRef]

8. Glencross, B.D.; Booth, M.; Allan, G.L. A feed is only as good as its ingredients-A review of ingredient evaluation strategies for aquaculture feeds. Aquac. Nutr. 2007, 13, 17-34. [CrossRef]

9. Barroso, F.G.; de Haro, C.; Sanchez-Muros, M.J.; Venegas, E.; Martinez-Sanchez, A.; Perez-Banon, C. The potential of various insect species for use as food for fish. Aquaculture 2014, 422-423, 193-201. [CrossRef]

10. Rossi, L.; Bibbiani, C.; Fierro-Sañudo, J.F.; Maibam, C.; Incrocci, L.; Pardossi, A.; Fronte, B. Selection of marine fish for integrated multi-trophic aquaponic production in the Mediterranean area using DEXi multi-criteria analysis. Aquaculture 2021, 535, 736402. [CrossRef]

11. Rumpold, B.A.; Schluter, O.K. Nutritional composition and safety aspects of edible insects. Mol. Nutr. Food Res. 2013, 57, 802-823. [CrossRef] [PubMed]

12. Makkar, H.P.S.; Tran, G.; Heuzé, V.; Ankers, P. State-of-the-art on use of insects as animal feed. Anim. Feed Sci. Technol. 2014, 197, 1-33. [CrossRef]

13. Van Huis, A.; Oonincx, D.G.A.B. The environmental sustainability of insects as food and feed. A review. Agron. Sustain. Dev. 2017, 37, 43. [CrossRef]

14. Henry, M.; Gasco, L.; Piccolo, G.; Fountoulaki, E. Review on the use of insects in the diet of farmed fish: Past and future. Anim. Feed Sci. Technol. 2015, 203, 1-22. [CrossRef]

15. Sánchez-Muros, M.J.; Barroso, F.G.; Manzano-Agugliaro, F. Insect meal as renewable source of food for animal feeding: A review. J. Clean. Prod. 2014, 65, 16-27. [CrossRef] 
16. Van Huis, A.; Van Itterbeeck, J.; Klunder, H.; Mertens, E.; Halloran, A.; Muir, G.; Vantomme, P. Edible Insects: Future Prospects for Food and Feed Security; FAO Forestry Paper: Rome, Italy, 2013; pp. 153-160.

17. Lock, E.; Arsiwalla, T.; Waagbo, R. Insect larvae meal as an alternative source of nutrients in the diet of Atlantic salmon (Salmo salar) postsmolt. Aquac. Nutr. 2016, 22, 1202-1213. [CrossRef]

18. Stadtlander, T.; Stamer, A.; Buser, A.; Wohlfahrt, J.; Leiber, F.; Sandrock, C. Hermetia illucens meal as fish meal replacement for rainbow trout on farm. J. Insects Food Feed 2017, 3, 165-175. [CrossRef]

19. Sogari, G.; Amato, M.; Biasato, I.; Chiesa, S.; Gasco, L. The Potential Role of Insects as Feed: A Multi-Perspective Review. Animals 2019, 9, 119. [CrossRef] [PubMed]

20. Diener, S.; Zurbrügg, C.; Tockner, K. Conversion of organic material by black soldier fly larvae: Establishing optimal feeding rates. Waste Manag. Res. 2009, 27, 603-610. [CrossRef] [PubMed]

21. Wang, Y.; Shelomi, M. Review of Black Soldier Fly (Hermetia illucens) as Animal Feed and Human Food. Foods $2017,6,91$. [CrossRef]

22. Xiao, X.; Jin, P.; Zheng, L.; Cai, M.; Yu, Z.; Yu, J.; Zhang, J. Effects of black soldier fly (Hermetia illucens) larvae meal protein as a fishmeal replacement on the growth and immune index of yellow catfish (Pelteobagrus fulvidraco). Aquac. Res. 2018, 49, 1569-1577. [CrossRef]

23. Sealey, W.M.; Gaylord, T.G.; Barrows, F.T.; Tomberlin, J.K.; McGuire, M.A.; Ross, C.; St-Hilaire, S. Sensory analysis of rainbow trout, Oncorhynchus mykiss, fed enriched black soldier fy prepupae, Hermetia illucens. J. World Aquac. Soc. 2011, 42, 34-45. [CrossRef]

24. Fronte, B.; Abramo, F.; Brambilla, F.; De Zoysa, M.; Miragliotta, V. Effect of hydrolysed fish protein and autolysed yeast as alternative nitrogen sources on gilthead sea bream (Sparus aurata) growth performances and gut morphology. Ital. J. Anim. Sci. 2019, 18, 799-808. [CrossRef]

25. Torrecillas, S.; Makol, A.; Caballero, M.J.; Montero, D.; Ginés, R.; Sweetman, J.; Izquierdo, M. Improved feed utilization, intestinal mucus production and immune parameters in sea bass (Dicentrarchus labrax) fed mannan oligosaccharides (MOS). Aquac. Nutr. 2011, 17, 223-233. [CrossRef]

26. Langeland, M.; Lindberg, J.E.; Lundh, T. Digestive Enzyme Activity in Eurasian Perch (Perca Fluviatilis) and Arctic Charr (Salvelinus Alpinus). J. Aquac. Res. Dev. 2013, 5, 1-15. [CrossRef]

27. Guerrera, M.C.; De Pasquale, F.; Muglia, U.; Caruso, G. Digestive enzymatic activity during ontogenetic development in zebrafish (Danio rerio). J. Exp. Zool. Part B 2015, 324B, 699-706. [CrossRef] [PubMed]

28. Lemieux, H.; Blier, P. Trypsin Activity Measurement in Fish and Mammals. J. Aquat. Food Prod. Technol. 2007, 16, 13-26. [CrossRef]

29. Yang, Y.; Wandler, A.M.; Postlethwait, J.H.; Guillemin, K. Dynamic evolution of the LPS-detoxifying enzyme intestinal alkaline phosphatase in zebrafish and other vertebrates. Front. Immunol. 2012, 6, 1-15. [CrossRef]

30. Leigh, S.C.; Nguyen-Phuc, B.Q.; German, D.P. The effects of protein and fiber content on gut structure and function in zebrafish (Danio rerio). J. Comp. Physiol. B 2018, 188, 237-253. [CrossRef]

31. Ahmadifar, E.; Sheikhzadeh, N.; Roshanaei, K.; Dargahi, N.; Faggio, C. Can dietary ginger (Zingiber officinale) alter biochemical and immunological parameters and gene expression related to growth, immunity and antioxidant system in zebrafish (Danio rerio)? Aquaculture 2019, 507, 341-348. [CrossRef]

32. Wang, A.; Zhang, Z.; Ding, Q.; Yang, Y.; Bindelle, J.; Ran, C.; Zhou, Z. Intestinal Cetobacterium and acetate modify glucose homeostasis via parasympathetic activation in zebrafish. Gut Microbes 2021, 13, 1-15. [CrossRef] [PubMed]

33. Fawley, J.; Gourlay, D.M. Intestinal alkaline phosphatase: A summary of its role in clinical disease. J. Surg. Res. 2016, 202, 225-234. [CrossRef] [PubMed]

34. Zhang, H.; Ding, Q.; Wang, A.; Liu, Y.; Teame, T.; Ran, C.; Yang, Y.; He, S.; Zhou, W.; Olsen, R.E.; et al. Effects of dietary sodium acetate on food intake, weight gain, intestinal digestive enzyme activities, energy metabolism and gut microbiota in cultured fish: Zebrafish as a model. Aquaculture 2020, 523, 735188. [CrossRef]

35. Arani, M.; Salati, A.P.; Safari, O.; Keyvanshokooh, S. Dietary supplementation effects of Pediococcus acidilactici as probiotic on growth performance, digestive enzyme activities and immunity response in zebrafish (Danio rerio). Aquac. Nutr. 2019, 25, 854-861. [CrossRef]

36. Li, S.; Ji, H.; Zhang, B.; Zhou, J.; Yu, H. Defatted black soldier fly (Hermetia illucens) larvae meal in diets for juvenile Jian carp (Cyprinus carpio var. Jian): Growth performance, antioxidant enzyme activities, digestive enzyme activities, intestine and hepatopancreas histological structure. Aquaculture 2017, 477, 62-70. [CrossRef]

37. Belghit, I.; Liland, N.S.; Gjesdal, P.; Biancarosa, I.; Menchetti, E.; Li, Y.; Waagbø, R.; Krogdahl, Å.; Lock, E. Black soldier fly larvae meal can replace fish meal in diets of sea-water phase Atlantic salmon (Salmo salar). Aquaculture 2019, 503, 609-619. [CrossRef]

38. Naef, V.; Mero, S.; Fichi, G.; D’Amore, A.; Ogi, A.; Gemignani, F.; Santorelli, F.M.; Marchese, M. Swimming in Deep Water: Zebrafish Modeling of Complicated Forms of Hereditary Spastic Paraplegia and Spastic Ataxia. Front. Neurosci. 2019, $13,1311$. [CrossRef] [PubMed]

39. Ogi, A.; Licitra, R.; Naef, V.; Marchese, M.; Fronte, B.; Gazzano, A.; Santorelli, F.M. Social Preference Tests in Zebrafish: A Systematic Review. Front. Vet. Sci. 2021, 7, 590057. [CrossRef] [PubMed]

40. Licitra, R.; Marchese, M.; Brogi, L.; Fronte, B.; Pitto, L.; Santorelli, F.M. Nutraceutical Screening in a Zebrafish Model of Muscular Dystrophy: Gingerol as a Possible Food Aid. Nutrients 2021, 13, 998. [CrossRef] 
41. Alestrom, P.; Holter, J.L.; Nourizadeh-Lillabadi, R. Zebrafish in functional genomics and aquatic biomedicine. Trends Biotechnol. 2006, 24, 15-21. [CrossRef] [PubMed]

42. Dahm, R.; Geisler, R. Learning from Small Fry: The Zebrafish as a Genetic Model Organism for Aquaculture Fish Species. Mar. Biotechnol. 2006, 8, 329-345. [CrossRef]

43. Ulloa, P.E.; Iturra, P.; Neira, R. Zebrafish as a model organism for nutrition and growth: Towards comparative studies of nutritional genomics applied to aquacultured fishes. Rev. Fish Biol. Fish. 2011, 21, 649-666. [CrossRef]

44. Ulloa, P.E.; Medrano, J.F.; Feijoo, C.G. Zebrafish as animal model for aquaculture nutrition research. Front. Genet. 2014, 5, 313. [CrossRef] [PubMed]

45. Yossa, R.; Sarker, P.K.; Karanth, S.; Ekker, M.; Vandenberg, G.W. Effects of dietary biotin and avidin on growth, survival, feed conversion, biotin status and gene expression of zebrafish Danio rerio. Comp. Biochem. Physiol. B 2011, 160, 150-158. [CrossRef] [PubMed]

46. Ribas, L.; Piferrer, F. The zebrafish (Danio rerio) as a model organism, with emphasis on applications for finfish aquaculture research. Rev. Aquac. 2013, 5, 1-32. [CrossRef]

47. Paige, C.; Hill, B.; Canterbury, J.; Sweitzer, S.; Romero-Sandoval, E.A. Construction of an affordable and easy-to-build zebrafish facility. J. Vis. Exp. 2014, 93, 1-9. [CrossRef] [PubMed]

48. Lawrence, C. The husbandry of zebrafish (Danio rerio): A review. Aquaculture 2007, 269, 1-20. [CrossRef]

49. Westerfield, M. The Zebrafish Book, 5th ed.; University of Oregon Press: Eugene, OR, USA, 2007; p. 45.

50. National Research Council. Nutrient Requirements of Fish and Shrimp; The National Academies Press: Washington, DC, USA, 2011.

51. Fronte, B.; Kim, C.H.; Bagliacca, M.; Casini, L.; De Zoysa, M. 1,3-1-6 ß-glucans enhance tissue regeneration in zebrafish (Danio rerio): Potential advantages for aquaculture applications. Aquac. Res. 2019, 50, 3163-3170. [CrossRef]

52. Silva, F.C.; Nicoli, J.R.; Zambonino-Infante, J.L.; Le Gall, M.M.; Kaushik, S.; Gatesoupe, F.J. Influence of partial substitution of dietary fish meal on the activity of digestive enzymes in the intestinal brush border membrane of gilthead sea bream, Sparus aurata and goldfish, Carassius auratus. Aquaculture 2010, 306, 233-237. [CrossRef]

53. Mazzei, M.; Fronte, B.; Sagona, S.; Carrozza, M.L.; Forzan, M.; Pizzurro, F.; Bibbiani, C.; Miragliotta, V.; Abramo, F.; Millanta, F.; et al. Effect of 1,3-1,6 $\beta$-Glucan on Natural and Experimental Deformed Wing Virus Infection in Newly Emerged Honeybees (Apis mellifera ligustica). PLoS ONE 2016, 11, e0166297. [CrossRef] [PubMed]

54. Hassantabar, F.; Fereidouni, A.E.; Ouraji, H.; Babaei, S.; Jafarpour, A. Comparison of growth and digestive enzymes activity of kutum (Rutilus kutum) during ontogeny fed with live prey and artificial feed. Aquac. Int. 2015, 23, 597-612. [CrossRef]

55. Hassanatabar, F.; Ouraji, H.; Esmaeili, A.; Babaei, S.S. Study of the Activities of Digestive Enzymes, Amylase and Alkaline Phosphatase, in Kutum Larvae, Rutilusfrisiikutum Fed Artemia Nauplii. World J. Fish Mar. Sci. 2013, 5, 266-270. [CrossRef]

56. Xiao, Z.; Storms, R.; Tsang, A. A quantitative starch-iodine method for measuring alpha-amylase and glucoamylase activities. Anal. Biochem. 2006, 351, 146-148. [CrossRef] [PubMed]

57. Muin, H.; Taufek, N.M.; Kamarudin, M.S.; Razak, S.A. Growth performance, feed utilization and body composition of Nile tilapia, Oreochromis niloticus (Linnaeus, 1758) fed with different levels of black soldier fly, Hermetia illucens (Linnaeus, 1758) maggot meal diet. Iran. J. Fish. Sci. 2017, 16, 567-577.

58. Karapanagiotidis, I.; Daskalopoulou, E.; Vogiatzis, I.; Rumbos, C.; Mente, E.; Athanassiou, C. Substitution of Fishmeal by Fly Hermetia Illucens Prepupae Meal in the Diet of Gilthead Seabream (Sparus Aurata). In Proceedings of the HydroMediT, Volos, Greece, 13-15 November 2014; pp. 110-114.

59. Magalhães, R.; Sánchez-López, A.; Leal, R.S.; Martínez-Llorens, S.; Oliva-Teles, A.; Peres, H. Black soldier fly (Hermetia illucens) pre-pupae meal as a fish meal replacement in diets for European seabass (Dicentrarchus labrax). Aquaculture 2017, 476, 79-85. [CrossRef]

60. Wang, G.; Peng, K.; Hu, J.; Yi, C.; Chen, X.; Wu, H.; Huang, Y. Evaluation of defatted black soldier fly (Hermetia illucens L.) larvae meal as an alternative protein ingredient for juvenile Japanese seabass (Lateolabrax japonicus) diets. Aquaculture 2019, 507, 144-154. [CrossRef]

61. Renna, M.; Schiavone, A.; Gai, F.; Dabbou, S.; Lussiana, C.; Malfatto, V.; Prearo, M.; Capucchio, M.T.; Biasato, I.; Biasibetti, E.; et al. Evaluation of the suitability of a partially defatted black soldier fly (Hermetia illucens L.) larvae meal as ingredient for rainbow trout (Oncorhynchus mykiss Walbaum) diets. J. Anim. Sci. Biotechnol. 2017, 1, 57. [CrossRef] [PubMed]

62. Gasco, L.; Stas, M.; Schiavone, A.; Rotolo, L.; De Marco, M.; Dabbou, S.; Renna, M.; Malfatto, V.; Lussiana, C.; Katz, H.; et al. Use of Black Soldier Fly (Hermetia illucens) meal in rainbow trout (Oncorhynchus mykiss) feeds. In Proceedings of the Aquaculture Europe Meeting, Rotterdam, The Netherlands, 20-23 October 2015.

63. Cardinaletti, G.; Randazzo, B.; Messina, M.; Zarantoniello, M.; Giorgini, E.; Zimbelli, A.; Bruni, L.; Parisi, G.; Olivotto, I.; Tulli, F. Effects of Graded Dietary Inclusion Level of Full-Fat Hermetia illucens Prepupae Meal in Practical Diets for Rainbow Trout (Oncorhynchus mykiss). Animals 2019, 9, 251. [CrossRef]

64. Bondari, K.; Sheppard, D.C. Soldier fly, Hermetia illucens L.; larvae as feed for channel catfish, Ictalurus punctatus (Rafinesque), and blue tilapia, Oreochromis aureus (Steindachner). Aquac. Fish. Manag. 1987, 18, 209-220. [CrossRef]

65. Kroeckel, S.; Harjes, A.G.E.; Roth, I.; Katz, H.; Wuertz, S.; Susenbeth, A.; Schulz, C. When a turbot catches a fly: Evaluation of a pre-pupae meal of the Black Soldier Fly (Hermetia illucens) as fish meal substitute—Growth performance and chitin degradation in juvenile turbot (Psetta maxima). Aquaculture 2012, 364-365, 345-352. [CrossRef] 
66. Rust, M.B. Nutritional physiology. In Fish Nutrition, 3rd ed.; Halver, J.E., Hardy, R.W., Eds.; The Academic Press: New York, NY, USA, 2002; pp. 367-452.

67. Vargas, A.; Randazzo, B.; Riolo, P.; Truzzi, C.; Gioacchini, G.; Giorgini, E.; Loreto, N.; Ruschioni, S.; Zarantoniello, M.; Antonucci, M.; et al. Rearing Zebrafish on Black Soldier Fly (Hermetia illucens): Biometric, Histological, Spectroscopic, Biochemical, and Molecular Implications. Zebrafish 2018, 15, 404-419. [CrossRef] [PubMed]

68. Tacon, A.G.J.; Metian, M. Global overview on the use of fish meal and fish oil in industrially compounded aquafeeds: Trends and future prospects. Aquaculture 2008, 285, 146-158. [CrossRef]

69. Zarantoniello, M.; Bruni, L.; Randazzo, B.; Vargas, A.; Gioacchini, G.; Truzzi, C.; Annibaldi, A.; Riolo, P.; Parisi, G.; Cardinaletti, G.; et al. Partial Dietary Inclusion of Hermetia illucens (Black Soldier Fly) Full-Fat Prepupae in Zebrafish Feed: Biometric, Histological, Biochemical, and Molecular Implications. Zebrafish 2018, 15, 519-532. [CrossRef] [PubMed]

70. Zarantoniello, M.; Randazzo, B.; Truzzi, C.; Giorgini, E.; Marcellucci, C.; Vargas-Abúndez, J.A.; Zimbelli, A.; Annibaldi, A.; Parisi, G.; Tulli, F.; et al. A six-months study on Black Soldier Fly (Hermetia illucens) based diets in zebrafish. Sci. Rep. 2019, 9, 8598. [CrossRef] [PubMed]

71. McCullough, J.S.; Ratcliffe, B.; Mandir, N.; Carr, K.E.; Goodlad, R.A. Dietary fibre and intestinal microflora: Effects on intestinal morphometry and crypt branching. Gut 1998, 42, 799-806. [CrossRef] [PubMed]

72. Castro, C.; Couto, A.; Pérez-Jiménez, A.; Serra, C.R.; Díaz-Rosales, P.; Fernandes, R.; Corraze, G.; Panserat, S.; Oliva-Teles, A. Effects of fish oil replacement by vegetable oil blend on digestive enzymes and tissue histomorphology of European sea bass (Dicentrarchus labrax) juveniles. Fish Physiol. Biochem. 2015, 42, 203-217. [CrossRef]

73. Pérez-Jiménez, A.; Cardenete, G.; Morales, A.E.; García-Alcázar, A.; Abellán, E.; Hidalgo, M.C. Digestive enzymatic profile of Dentex dentex and response to different dietary formulations. Comp. Biochem. Physiol. A Mol. Integr. Physiol. 2009, 154, 157-164. [CrossRef] [PubMed]

74. García-Gasca, A.; Galaviz, M.A.; Gutiérrez, J.N.; García-Ortega, A. Development of the digestive tract, trypsin activity and gene expression in eggs and larvae of the bullseye puffer fish Sphoeroides Annulatus. Aquaculture 2006, 251, 366-376. [CrossRef]

75. Bates, J.M.; Akerlund, J.; Mittge, E.; Guillemin, K. Intestinal alkaline phosphatase detoxifies lipopolysaccharide and prevents inflammation in zebrafish in response to the gut microbiota. Cell Host Microbe 2007, 2, 371-382. [CrossRef] [PubMed]

76. Yousefi, S.; Hoseinifar, S.H.; Paknejad, H.; Hajimoradloo, A. The effects of dietary supplement of galactooligosaccharide on innate immunity, immune related genes expression and growth performance in zebrafish (Danio rerio). Fish Shellfish Immunol. 2018, 73, 192-196. [CrossRef]

77. Carneiro, W.F.; Castro, T.F.D.; Orlando, T.M.; Meurer, F.; de Jesus Paula, D.A.; Virote, B.D.C.R.; Vianna, A.R.D.C.B.; Murgas, L.D.S Replacing fish meal by Chlorella sp. meal: Effects on zebrafish growth, reproductive performance, biochemical parameters and digestive enzymes. Aquaculture 2020, 528, 735612. [CrossRef]

78. Fang, L.; Liang, X.F.; Zhou, Y.; Guo, X.Z.; He, Y.; Yi, T.L.; Liu, L.W.; Yuan, X.C.; Tao, Y.X. Programming effects of high-carbohydrate feeding of larvae on adult glucose metabolism in zebrafish, Danio rerio. Br. J. Nutr. 2014, 111, 808-818. [CrossRef] [PubMed] 